\title{
A comprehensive review of the literature on epilepsy in selected countries in emerging markets
}

\author{
Mallik Angalakuditi' \\ Nupur Angalakuditi ${ }^{2}$ \\ 'Georgia State University, Atlanta, \\ GA; ${ }^{2}$ New York Medical College, \\ Valhalla, NY, USA
}

This article was published in the following Dove Press journal:

Neuropsychiatric Disease and Treatment

28 September 2011

Number of times this article has been viewed
Aims: To perform a systematic literature review of studies in peer reviewed journals on the epidemiology, economics, and treatment patterns of epilepsy in selected countries in emerging markets.

Methods: A literature search was performed using relevant search terms to identify articles published from 1999 to 2000 on the epidemiology, economics, and treatment patterns of epilepsy. Studies were identified through electronic Embase ${ }^{\circledR}$, Cochrane $^{\odot}, \operatorname{MEDLINE}^{\circledR}$, and PubMed ${ }^{\circledR}$ databases. Manual review of bibliographies allowed for the detection of additional articles.

Results: Our search yielded 65 articles. These articles contained information relevant to epidemiology $(n=16)$, treatment guidelines $(n=4)$, treatment patterns $(n=33)$, unmet needs $(n=4)$, and economics $(n=8)$. From a patient perspective, patients with less than or equal to two adverse events (AEs) while taking anti-epileptic drugs (AEDs) had significantly lower annual costs than those having greater than or equal to three AEs, as did patients with fewer seizures. The overall mean annual cost for epilepsy per patient ranged from US\$773 in China to US\$2646 in Mexico. Prevalence data varied widely and were found for countries including Arab League Members, China, India, and Taiwan. In Turkey, active prevalence rates ranged from 0.08/1000 to 8.5/1000, and in Arab countries, active prevalence ranged from 0.9/1000 in Sudan to $6.5 / 1000$ in Saudi Arabia. Seventeen different AEDs were used in the identified studies. The most common AEDs utilized were phenobarbital (21.7\%), valproate (17.5\%), and tiagabine (16.4\%). In all studies, the use of AEDs resulted in an increase of patients who became seizure free and a reduction in seizure frequency and severity.

Conclusion: Few studies have examined the prevalence and incidence of epilepsy in emerging markets and study limitations tend to underestimate these rates at all times. More costeffectiveness, cost-minimization, and cost-benefit analyses must be performed to enhance the data on the economics of epilepsy and its therapy in regions with insufficient resources and those emerging markets which contain the majority of the world's population. And finally, the study found that generic AEDs are frequently used to successfully treat patients with epilepsy in emerging markets.

Keywords: emerging markets, epilepsy, seizures, epidemiology, treatment patterns, guidelines, economics

\section{Introduction}

Epilepsy is recognized as a collection of heterogeneous syndromes characterized by additional conditions that coexist with seizures and impacts over 50 million people worldwide. ${ }^{1}$ Cognitive, emotional, and behavioral comorbidities are common.

Seizures are typically divided into two main categories: partial (focal) and generalized. Generalized seizures affect both cerebral hemispheres from the onset of
Correspondence: Mallik Angalakuditi Georgia State University,

Atlanta, GA, USA

Tel +l 2037985150

Email hydmallik02@hotmail.com 
the seizure. Seizures produce loss of consciousness, either for long periods of time or temporarily, and are sub-categorized into generalized tonic-clonic, myoclonic, absence, or atonic subtypes. ${ }^{2}$ Partial seizures affect an area within one cerebral hemisphere of the brain and are the most recurring type of seizure experienced by patients with epilepsy. ${ }^{3}$ Partial seizures are further subdivided into simple partial seizures, where consciousness is retained; and complex partial seizures, where consciousness is diminished or lost. ${ }^{3}$

In the treatment of epilepsy, no one anti-epileptic drug (AED) has been shown to be the most effective, and all AEDs have published side effects. AEDs are selected following consideration of side effects, ease of use, cost, and physician knowledge. Patients with newly diagnosed epilepsy who require treatment can be started on standard, first-line AEDs such as carbamazepine, phenytoin, valproic acid, or phenobarbital. Alternatively, newer AEDs introduced in the past decade may be used. These include gabapentin, lamotrigine, oxcarbazepine, or topiramate. ${ }^{4}$ Between $70 \%$ and $80 \%$ of individuals are successfully treated with one of the AEDs now available and success rates primarily depend on the etiology of the seizure disorder. ${ }^{4}$ However, the remaining 20\%-30\% of patients have either intractable or uncontrolled seizures or suffer significant adverse side effects to medication. ${ }^{4}$ As with the selection of first-line therapy, choosing the appropriate drug for the treatment of refractory epilepsy must be based on the appreciation of each drug's characteristics and risks for each individual patient.

An emerging market economy is defined as an economy with low-to-middle per capita income. ${ }^{5}$ Such countries constitute approximately $80 \%$ of the global population, are often rapidly-growing and represent about $20 \%$ of the world's economies. ${ }^{5}$ Although the term emerging market is loosely defined, countries that fall into this category, range from big to small, and are often considered emerging because of development and reform programs that have been put in place to launch their markets globally. ${ }^{5}$ Consequently, although China is considered one of the world's foremost economic leaders, it is grouped into the emerging market category together with much smaller economies with fewer resources, such as Sudan or Bulgaria.

Epilepsy is common in patients admitted to hospitals in emerging markets. ${ }^{6}$ However, there are reported differences in the epidemiology, economic burden, and outcome of epilepsy in these regions compared to high-income countries; although few data from the former regions exist. ${ }^{6}$ Applying the International League Against Epilepsy definition of epilepsy is problematic in these areas, as patients often arrive at health facilities without adequate documentation of the seizure duration. ${ }^{7}$

The goal of treatment for patients with epilepsy is no seizures with little to no side effects. However, due to variabilities in clinical presentation and available resources, treatments are highly individualized and vary widely. The objective of this study is to systematically review the literature on epilepsy to identify incidence and prevalence rates, economic data, unmet needs, and treatment patterns in those emerging markets which contain the majority of the world's population.

\section{Methods}

To ensure an extensive examination of the literature, this study included all published randomized clinical trials and observational peer-reviewed studies that examined factors associated with epilepsy in emerging markets. A comprehensive search of the literature was performed using PubMed, EMBASE, and Cochrane Review databases on the following topics concerning epilepsy in emerging markets: epidemiology, including prevalence and incidence; economics, including burden of disease, effects on productivity, and other economic issues; guidelines for treatment; treatment patterns; drug usage patterns; and unmet needs.

\section{Search strategy and study selection}

The initial search strategy was developed in the PubMed/ MEDLINE database (Table 1). A search string was constructed utilizing varied approaches to identify the most comprehensive and effective method for retrieving studies specific to the study objective. Methods were explored using MeSH, (PubMed/MEDLINE's controlled vocabulary indexing hierarchy), as well as a detailed examination of key terminology that would afford the best retrieval. Provisions were made to include varied constructs of search terms with the use of the asterisk as a truncation tool (Example: epidemiolog* to ensure retrieval of epidemiological, epidemiology, etc.) Additional constraints were also placed upon the final search strategy to limit the retrieval to English, humans, and studies published in the past 10 years at the time of the search (between 1999 and 2010).

Following completion of the PubMed/MEDLINE search on January 4, 2011, the EMBASE and Cochrane databases were searched with comparable search strings on January 14, 2011 and January 18, 2011 respectively; duplicate citations, if present, were identified and removed. Figure 1 illustrates the various steps in the study selection 
Table I Prevalence of epilepsy in emerging markets

\begin{tabular}{|c|c|c|c|c|c|}
\hline \multirow[t]{2}{*}{ Region } & \multirow[t]{2}{*}{ Age group } & \multirow[t]{2}{*}{ Time period } & \multicolumn{2}{|c|}{$\begin{array}{l}\text { Prevalence// } 000 \\
\text { inhabitants }\end{array}$} & \multirow[t]{2}{*}{ Citation } \\
\hline & & & Lifetime & Active & \\
\hline Saudi Arabia & Adults and children & 1989 & NR & 6.54 & Al Rajeh et al"I \\
\hline Members of the Arab League & Adults and children & $1950-2008$ & Libya & NR & Benamer and Grosset ${ }^{12}$ \\
\hline (Mauritania, Morocco, Algeria, & & & 2.3 & & \\
\hline Tunisia, Libya, Egypt, Sudan, Djibouti, & & & Tunisia & & \\
\hline Comoros, Somalia, Eritrea, Lebanon, & & & 4.0 & & \\
\hline Jordan, Syria, Iraq, Saudi Arabia, & & & Saudi Arabia & & \\
\hline Qatar, Kuwait, United Arab Emirates, & & & 6.5 & & \\
\hline Oman, Bahrain, and Yemen) and & & & Sudan & & \\
\hline The Palestine territory (Gaza strip & & & $0.9-2.1$ & & \\
\hline \multicolumn{6}{|l|}{ and West Bank) } \\
\hline Argentina & Children & 1991 & 3.2 & 2.6 & Somoza et $\mathrm{al}^{8}$ \\
\hline Argentina & Adults and children & 1991 & 6.2 & 3.8 & Melcon et $\mathrm{al}^{9}$ \\
\hline Argentina & Children & 1994 & 71.9 & 64.8 & Somoza et $\mathrm{al}^{10}$ \\
\hline China/Hong Kong & Children & 1997 & NR & 1.52 & Kwong et $\mathrm{al}^{13}$ \\
\hline China/Hong Kong & Adults & 2002 & NR & 1.54 & Fong et $\mathrm{al}^{14}$ \\
\hline China/Hong Kong & Adults and children & 1982-2002 & NR & 4.5 & Hui et $\mathrm{al}^{15}$ \\
\hline Colombia & Adults and children & $1995-1996$ & 11.3 & 10.1 & Velez and Eslava-Cobos ${ }^{17}$ \\
\hline India & Children & $199 \mid$ & $N R$ & 2.33 & Shah et $\mathrm{al}^{18}$ \\
\hline Russia & Adults and children & $2003-2008$ & NR & 3.4 & Halász et al ${ }^{19}$ \\
\hline Taiwan & Adults & 2001 & 3.14 & 2.77 & Chen et $\mathrm{al}^{16}$ \\
\hline Turkey & Adults and children & $1999-2000$ & 0.08 & NR & Onal et $\mathrm{a}^{20}$ \\
\hline Turkey & Children & 1996 & 0.08 & NR & Serdaroğlu et $\mathrm{a}^{21}$ \\
\hline Turkey & Adults and children & 2004-2005 & 12.2 & 8.5 & Calisir et $\mathrm{al}^{22}$ \\
\hline Turkey & Adults and children & 2000 & 6.0 & 5.0 & Velioglu et $\mathrm{al}^{23}$ \\
\hline
\end{tabular}

Abbreviation: NR, not reported.

process via a flow diagram. All citations were initially screened for relevancy and included where appropriate. Each abstract and, if needed, full-text article was reviewed for eligibility prior to inclusion in the current analysis. Reference lists of relevant studies identified by searching the three databases (PubMed/MEDLINE, EMBASE, and

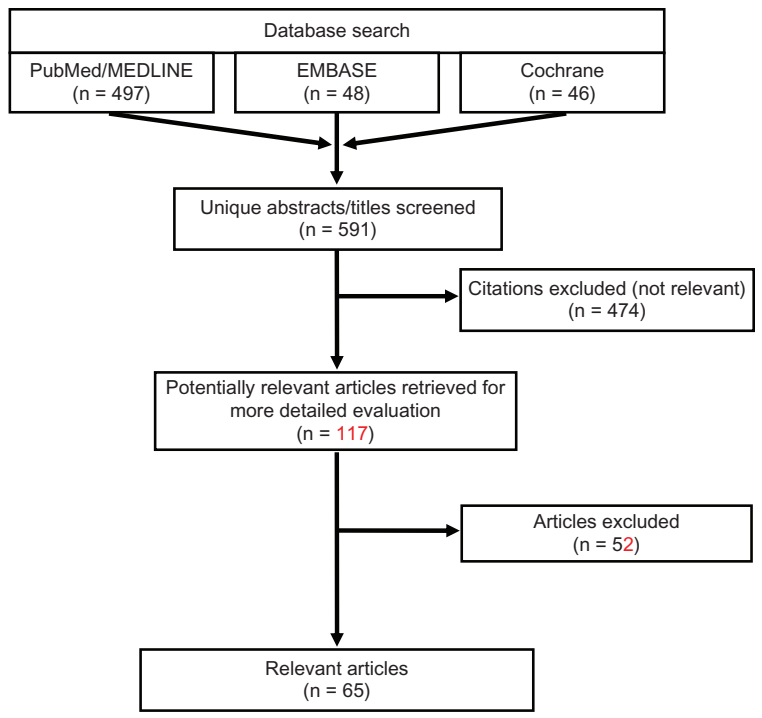

Figure I Literature review flow diagram.
Cochrane) were further searched manually to identify any additional publications of interest. Articles were excluded if they did not focus on epilepsy, if they did not provide information about the outcomes of interest, if the sample size was $<50$, or if they pertained to infantile or pediatric populations $<12$ years old. Articles were excluded from this review if the articles were not published in English or if the subjects studied were not humans. Reviews, letters/ comments, and case studies were also excluded from the review, but associated primary references were examined to verify they were identified by our search strategy. After abstracts were screened, full texts of the selected articles were reviewed to ensure relevance and presence of desired information.

\section{Data abstraction}

A structured abstraction table consisting of descriptive characteristics of the studies such as study objective/ hypothesis; data collection methods (study design and analytics); study population characteristics (sample size, subject inclusion and exclusion criteria); treatments; outcomes; and limitations was used to extract the data from all relevant articles. 


\section{Results}

Our comprehensive search yielded a total of 65 articles (Figure 1). There were 16 articles found to have information relevant to epidemiology, four treatment guidelines, 33 articles which discussed treatment patterns, four articles discussing unmet needs, and eight economic articles. No articles were found addressing the topic of drug usage trends. Since many of the studies included in this review evaluated multiple topics, there was overlap between the categories. Therefore, many of the articles summarized below have been cross-categorized and, when totaled, the numbers of articles cited in each category add up to more than the 65 indicated.

\section{Epidemiology of epilepsy}

\section{Prevalence}

Studies were found describing the prevalence in Algeria, Argentina, Bahrain, China, Colombia, Comoros, Djibouti,Egypt, Eritrea, Gaza strip, India, Iraq, Jordan, Lebanon, Kuwait, Libya, Mauritania, Morocco, Oman, Qatar, Russia, Saudi Arabia, Somalia, Sudan, Syria, Taiwan, Tunisia, Turkey, United Arab Emirates, West Bank, and Yemen. These data are summarized in Table 1. Studies may provide data for lifetime prevalence, which approximate cumulative incidence, and/or active prevalence, which measures current seizures or current use of anti-epileptic drugs.

In the literature identified for this review, the prevalence of epilepsy in emerging markets varied according to the population studied. For example, three studies discussed the prevalence of epilepsy in Argentina. In the primary school children population, the lifetime and active prevalence rates were determined to be $3.2 / 1000$ and 2.6/1000, respectively in one report, while lifetime and active prevalence was estimated to be $6.2 / 1000$ and 3.8/1000 in another. ${ }^{89}$ Another examination found a lifetime prevalence of 71.9/1000 and an active prevalence of $64.8 / 1000$ in the special schools of Buenos Aires that contain student populations with physical or mental disorders and learning problems. ${ }^{10}$
The prevalence rate for active epilepsy in Saudi Arabia was reported in two separate studies. In the first, prevalence was found to be 6.54/1000 inhabitants. ${ }^{11}$ A second study reported prevalence rates for several Arab countries. In this study, epilepsy prevalence ranged between $0.9 / 1000$ in Sudan and 6.5/1000 in Saudi Arabia, reporting a median of 2.3/1000 inhabitants. ${ }^{12}$

Three studies addressed the epidemiology of epilepsy in China. The prevalence of active epilepsy in China was estimated to be 1.52/1000 in one study and 1.54 per 1000 inhabitants in another. ${ }^{13,14}$ Hui and Kwan estimated that approximately 4.5/1000 individuals in Hong Kong have active epilepsy. ${ }^{15}$ The lifetime and active prevalence rates of adult patients with epilepsy in Taiwan was estimated to be $3.14 / 1000$ and $2.77 / 1000$, respectively. ${ }^{16}$

In Colombia, the general prevalence of epilepsy was determined to be $11.3 / 1000 .{ }^{17}$ In India, they found that the age-specific prevalence of epilepsy in school-going children was 3.44/1000 for those aged 11-14 years and 2.33/1000 for those age $15-18$ years. ${ }^{18}$ In the Russian Federation, an age-adjusted prevalence of epilepsy of 3.40/1000 was reported. ${ }^{19}$

Four studies examined the prevalence of epilepsy in Turkey with active rates ranging from $0.8 / 1000$ to $8.5 / 1000$ and lifetime rates from $5 / 1000$ to $12.2 / 1000$. Two separate studies found the active prevalence rate to be $0.08 / 1000$, while in Bursa a prevalence rate for active epilepsy was $8.5 / 1000$, and lifetime prevalence was reported to be $12.2 / 1000 .^{20-22}$ Lastly, a lifetime prevalence of 6/1000 and an active epilepsy prevalence of 5/1000 was also reported..$^{23}$

\section{Incidence}

Only one study was identified that studied the incidence of epilepsy in emerging markets and it reported an annual incidence of 174 per 100,000 persons in Qatar in 2001.12

\section{Economics of epilepsy}

Articles from Bulgaria, China, India, Korea and Mexico were identified. These data are summarized in Tables 2 and 3.

Table 2 Societal perspective - economic data

\begin{tabular}{|c|c|c|c|c|c|}
\hline Year & Country & Patient population & Costs of epilepsy & Cost burden & Reference \\
\hline \multirow[t]{3}{*}{2008} & China & Adults and children & $\downarrow 103 ¥(16$ USD) & Shanghai-mean costs of health care contact with town doctors & Ding et $\mathrm{al}^{28}$ \\
\hline & & & $\downarrow 12 ¥(2$ USD) & Ningxia-health care costs to town doctors & \\
\hline & & & $\uparrow I 0 ¥(I .5$ USD $)$ & Ningxia-time costs to town doctors & \\
\hline 2009 & China & Adults and children & I968¥ (289 USD) & Loss of productivity & Hong et $\mathrm{al}^{24}$ \\
\hline \multirow[t]{2}{*}{2001} & India & Adults & 147 rupees (3 USD) & Drug monitoring service to hospital & Rane et $\mathrm{al}^{25}$ \\
\hline & & & 22 rupees $(0.50$ USD) & Drug monitoring service to hospital per seizure prevented & \\
\hline
\end{tabular}

Abbreviations: $¥$, Chinese yuan, renminbi; USD, United States dollar; $\uparrow$, increased; $\downarrow$, decreased. 
Table 3 Patient perspective - economic data

\begin{tabular}{|c|c|c|c|c|c|}
\hline Year & Country & Patient population & Outcome measure & Mean cost (USD) & Reference \\
\hline \multirow[t]{6}{*}{2008} & Bulgaria & Adults & $\leq 2 \mathrm{AEs}$ & $339 €(\$ 487)$ & Balabanov et $\mathrm{al}^{27}$ \\
\hline & & & $\geq 2 \mathrm{AEs}$ & $806 €(\$ 1158)$ & \\
\hline & & & CBZ patients $>26$ weeks between seizures & $386 €(\$ 555)$ & \\
\hline & & & $<26$ weeks between seizures & $810 €(\$ 1164)$ & \\
\hline & & & $C B Z \geq 50 \%$ seizure reduction & $403 €(\$ 579)$ & \\
\hline & & & $C B Z \leq 50 \%$ seizure reduction & $931 €(\$ 1338)$ & \\
\hline \multirow[t]{4}{*}{2008} & China & Adults and children & Shanghai: I-year expenses per & I494¥ decreased to $92 ¥$ & Ding et $\mathrm{a}^{28}$ \\
\hline & & & PB treated patient & at I year $(\$ 234$ to $\$ 14)$ & \\
\hline & & & Ningxia: I-year expenses per & $213 ¥$ decreased to $46 ¥$ & \\
\hline & & & PB treated patient & at I year $(\$ 33$ to $\$ 7)$ & \\
\hline \multirow[t]{4}{*}{2009} & China & Adults and children & Direct medical care costs & $2529 ¥(\$ 395)$ & Hong et $\mathrm{a}^{24}$ \\
\hline & & & Antiepileptic drugs & $|65| ¥(\$ 258)$ & \\
\hline & & & Non-medical direct costs & $756 \#(\$ 118)$ & \\
\hline & & & Annual cost for epilepsy/patient & $5253 ¥(\$ 821)$ & \\
\hline \multirow[t]{4}{*}{2001} & India & Adults & TDM cost per patient & |47₹ (\$1 |4) & Rane et $a^{25}$ \\
\hline & & & TDM cost patient charged & $30 ₹(\$ 0.65)$ & \\
\hline & & & TDM cost to hospital per seizure prevented & $22 ₹(\$ 0.48)$ & \\
\hline & & & TDM cost to patient per seizure prevented & $5 ₹(\$ 0.10)$ & \\
\hline \multirow[t]{4}{*}{2005} & India & Adults & Cost of drug at entry - monotherapy & $2276 ₹(\$ 49)$ & Thomas et al ${ }^{29}$ \\
\hline & & & Cost of drug at entry - polytherapy & $3629 ₹(\$ 79)$ & \\
\hline & & & Cost of drug at last follow-up - monotherapy & I898₹ $(\$ 4 \mid)$ & \\
\hline & & & Cost of drug at last follow-up - polytherapy & $4929 ₹(\$ 107)$ & \\
\hline \multirow[t]{2}{*}{2006} & Mexico & Adults and children & Annual healthcare cost per patient & 2646 USD & Garcia- \\
\hline & & & & & Contreras et al ${ }^{30}$ \\
\hline
\end{tabular}

Note: USD conversion rates as at August 21, 2011.

Abbreviations: $¥$, Chinese yuan, renminbi; USD, United States dollar; $€$, euro; PB, phenobarbital; TDM, therapeutic drug monitoring.

\section{Societal perspective}

From a societal perspective, costs due to loss of productivity averaged US\$289 per patient per year in China (Table 2). ${ }^{24}$ In India, the direct costs were calculated to be 147 rupees (US\$3.26) to hospitals per epileptic patient, while the cost of monitoring therapeutic drugs to the hospital, per seizure prevented, was 22.35 rupees (US $\$ 0.50){ }^{25}$

\section{Payer perspective}

In Korea, from the payer's perspective, adjunctive therapy led to the incremental cost-effectiveness ratios being estimated at US $\$ 44$ per seizure-free day per adult patient and US\$11,084 per quality-adjusted life years gained. ${ }^{26}$

\section{Patient perspective}

From a patient perspective, Bulgarian patients with one or two adverse events (AEs) had significantly lower annual costs (mean €338.73) than those with more than two AEs (mean €806.03) while taking AED monotherapy (Table 3). Monotherapy patients with fewer seizures also showed significantly lower costs (mean €85.97), compared with patients with more frequent seizures (mean $€ 810.43$ ). Patients on AED therapy, with $50 \%$ or more seizure reduction compared with baseline, showed significantly lower costs (mean 402.67€) than those with worse control (mean $€ 931.30){ }^{27}$

In rural Shanghai and Ningxia, China, the total 1-year expenses per patient before AED treatment were 1494.30¥ (US\$229) and 213.09¥ (US\$33), respectively, and these expenses decreased to $91.52 ¥$ (US\$14) and 45.90¥ (US\$7), respectively $(P<0.05)$ following treatment for 1 year. ${ }^{28}$ In another study from China, direct medical care costs were $2529 ¥$ (US\$372) per year per patient, of which antiepileptic drugs (1651¥ or US\$243) accounted for the major cost component. ${ }^{24}$ Nonmedical direct costs were much less than direct health care costs, averaging approximately $756 ¥$ (US\$111). The overall mean annual cost for epilepsy per patient in this series was approximately $5253 ¥$ (US\$773), and these costs accounted for more than half of the mean annual income. ${ }^{24}$

In India, direct costs were calculated, including cost to the hospital of providing the therapeutic drug monitoring (TDM) service, cost to the hospital per seizure prevented, and cost to the patient per seizure prevented..$^{25}$ The cost per patient of the TDM service to the hospital was 147 rupees (US\$3.26), while each patient was charged only 30 rupees 
(US\$0.67) per sample, reflecting the cost of the consumables only. The cost of TDM to the hospital per seizure prevented was 22.35 rupees (US\$0.50) while the cost to the patient was 4.50 rupees (US\$0.10). A second study found that the cost of drug therapy for patients at entry ranged from 2276 rupees (US\$50.46) to 3629 rupees (US\$80.46). At the time of last follow-up, it ranged from 1898 rupees (US\$42.08) to 4929 rupees (US\$109.28). ${ }^{29}$

Lastly, in Mexico, the annual mean health care cost per treated patient was found to be US\$2646. Ambulatory health care contributed to $76 \%$ of the total, and hospital health care contributed $24 \%$. $^{30}$

\section{Treatment guidelines}

The goal of epilepsy treatment is to maintain a normal lifestyle, ideally, by complete seizure control with minimal side effects. For the majority of patients with epilepsy, AED therapy is used. The quality of care and therapeutic outcome may differ across countries because of numerous variations in medical systems. Few additional studies were identified that addressed ways by which care providers could more effectively identify patients with epilepsy or determine an appropriate therapy.

In China, age-varying differences between the effectiveness of carbamazepine and valproate for the treatment of generalized onset and partial onset seizures were reported in a study that suggested valproate may be more effective at treating epilepsy in younger patients, while carbamazepine may be more effective at treating patients older than $30 .{ }^{31}$ An electroencephalography screening process by which high-risk patients can be better screened was described as well as a method used to aid health care providers in the identification of patients with generalized tonic-clonic seizures. ${ }^{32,33}$

\section{Treatment patterns}

In the articles identified, data on the treatment patterns of 12,317 patients with generalized or partial onset epilepsy were found for countries including Argentina, Brazil, China, Czech Republic, India, Korea, Poland, Russia, and Taiwan. These data are summarized in Table 4. Seventeen different AEDs were used in these studies. The proportion of patients receiving each AED was phenobarbital (21.7\%), valproate (17.5\%), tiagabine (16.4\%), oxcarbazepine (8.3\%), levetiracetam $(8.1 \%)$, topiramate $(7.2 \%)$, eslicarbazepine acetate $(5.8 \%)$, lacosamide $(3.9 \%)$, lamotrigine $(2.1 \%)$, pregabalin $(1.9 \%)$, and clobazam (1.6\%). Zonisamide, primidone, clonazepam, phenytoin, gabapentin, and carbamazepine were used in $<1 \%$ of the population each. In all studies, the use of these AEDs resulted in an increase of patients who became seizure free and a reduction of seizure frequency and severity.

\section{Unmet needs}

The literature review identified five articles discussing the unmet needs of patients with epilepsy in emerging markets. There were two studies of the Indian population and one study found for each of the countries of Bahrain, the Czech Republic, and Kuwait. In general, the articles identified the need for developing treatment strategies, counseling therapies, and social support for people with epilepsy to improve their quality of life. ${ }^{34,35}$ As the mean delay in diagnosis is $1.5 \pm 4$ years in parts of India, facilities for epilepsy surgery, therapeutic drug monitoring, and services of clinical psychologist or medical social workers are also needed. ${ }^{36}$ In Kuwait, objections to shaking hands with, working with, marrying, and employing patients with epilepsy were reported by $16.0 \%, 24.8 \%, 71.6 \%$, and $45.2 \%$, of the general population, respectively. ${ }^{37}$ Therefore, continuing effective educational interventions are needed to improve the understanding of epilepsy and to diminish social discrimination and misconceptions against these patients. $^{37}$

\section{Discussion}

This review is a thorough study of epilepsy in emerging markets summarizing the available literature on epidemiology, economics, unmet needs, treatment and drug usage patterns, and guidelines for the treatment of epilepsy in emerging markets. To more fully grasp the information found in this review concerning epilepsy and its treatment in emerging markets, it is useful to compare these findings to data from developed countries with higher per capita incomes.

Because it is often less complicated to obtain information regarding prevalence than incidence, many more prevalence studies of epilepsy from diverse populations were found. In general, prevalence rates per 1000 individuals varied widely in this review. In Argentina and China, rates ranged from 2.6-3.8 and 1.5-4.5 respectively. ${ }^{8,9,13,15}$ In India, prevalence was reported to be 2.3 and in Turkey, rates ranged from 0.08 to 8.5 individuals. . $^{182,202}$ Studies from Argentina reported a wide range of per 1000 population rates of 3.2, 6.2 , and 71.9 in the general school, general, and the special school populations, respectively. The prevalence study from southern Sudan was based on a population estimate 
Table 4 Clinical trials of therapies for epilepsy

\begin{tabular}{|c|c|c|c|c|c|}
\hline Country & $\begin{array}{l}\text { Therapeutic } \\
\text { agent(s) }\end{array}$ & $\begin{array}{l}\text { Patient } \\
\text { population }\end{array}$ & Trial design & Key findings & Reference \\
\hline Brazil & Clobazam & $\begin{array}{l}\text { Partial onset } \\
\text { patients with } \\
\text { refractory epilepsy }\end{array}$ & Retrospective & $\begin{array}{l}\text { Following treatment, } 7 \% \text { of patients were } \\
\text { seizure free, } 49 \% \text { had } \geq 50 \% \text { of improvement } \\
\text { in seizure control, } 40 \% \text { had }<50 \% \text { of } \\
\text { improvement in seizure control. }\end{array}$ & $\begin{array}{l}\text { Montenegro } \\
\text { et } \mathrm{a}^{50}\end{array}$ \\
\hline Brazil & $\begin{array}{l}\text { Clobazam as } \\
\text { add-on agent }\end{array}$ & Generalized & Retrospective & $\begin{array}{l}\text { Following treatment, } 20 \% \text { of patients were } \\
\text { seizure-free, } 25 \% \text { had more than } 75 \% \\
\text { improvement in seizure control, } \\
10 \% \text { had more than } 50 \% \text { and } 26 \% \\
\text { were non responders to treatment. }\end{array}$ & $\begin{array}{l}\text { Montenegro } \\
\text { et } \mathrm{a}^{51}\end{array}$ \\
\hline China & Phenobarbital & Generalized & $\begin{array}{l}\text { Prospective } \\
\text { observational }\end{array}$ & $\begin{array}{l}\text { Following treatment, } 78 \% \text { of the patients } \\
\text { had a } 50 \% \text { or greater reduction in seizure } \\
\text { frequency and } 43 \% \text { were seizure free. }\end{array}$ & Liu et $\mathrm{al}^{52}$ \\
\hline China & $\begin{array}{l}\text { Topiramate } \\
\text { monotherapy vs } \\
\text { add-on agent }\end{array}$ & $\begin{array}{l}\text { Generalized and } \\
\text { Partial onset }\end{array}$ & $\begin{array}{l}\text { Prospective } \\
\text { observational }\end{array}$ & $\begin{array}{l}\text { The rate of AEs was significantly higher } \\
\text { with use of topiramate as monotherapy } \\
\text { than as adjunctive therapy. }\end{array}$ & Lu et $\mathrm{a}^{53}$ \\
\hline China & $\begin{array}{l}\text { Zonisamide as } \\
\text { add-on agent }\end{array}$ & $\begin{array}{l}\text { Partial onset } \\
\text { refractory epilepsy }\end{array}$ & RCT & $\begin{array}{l}\text { Zonisamide showed significantly greater } \\
\text { efficacy compared with placebo. }\end{array}$ & Lu et al ${ }^{54}$ \\
\hline China & $\begin{array}{l}\text { Topiramate } \\
\text { monotherapy vs } \\
\text { add-on agent }\end{array}$ & Generalized & Retrospective & $\begin{array}{l}\text { The percentage of seizure-free patients was } \\
69 \% \text { in the topiramate monotherapy group } \\
\text { and } 42 \% \text { in the topiramate add-on group. }\end{array}$ & Lu et $a^{55}$ \\
\hline China & $\begin{array}{l}\text { Valproate and } \\
\text { Primidone }\end{array}$ & $\begin{array}{l}\text { Partial onset } \\
\text { patients unresponsive } \\
\text { to carbamazepine }\end{array}$ & $\begin{array}{l}\text { Prospective } \\
\text { observational }\end{array}$ & $\begin{array}{l}\text { Significantly more patients on Valproate } \\
(51 \%) \text { achieved a greater than } 50 \% \text { seizure } \\
\text { reduction than on Primidone }(34 \%) \text {. }\end{array}$ & Sun et $\mathrm{al}^{56}$ \\
\hline China & $\begin{array}{l}\text { Levetiracetam as } \\
\text { add-on agent }\end{array}$ & Partial onset & RCT & $\begin{array}{l}\text { Levetiracetam significantly decreased } \\
\text { weekly partial-onset seizure frequency } \\
\text { over placebo by } 27 \% \text {. }\end{array}$ & Wu et al ${ }^{57}$ \\
\hline China & $\begin{array}{l}\text { Levetiracetam as } \\
\text { add-on agent }\end{array}$ & Partial onset & RCT & $\begin{array}{l}\text { The proportion of patients with a } \\
\text { minimum of } 50 \% \text { reduction in partial } \\
\text { seizure frequency occurred in } 46 \% \text { of the } \\
\text { treatment group, compared with } 39 \% \\
\text { of the placebo group. }\end{array}$ & Xiao et $a^{58}$ \\
\hline Czech Republic & Levetiracetam & $\begin{array}{l}\text { Generalized and } \\
\text { partial onset }\end{array}$ & Retrospective & $\begin{array}{l}\text { A significant decrease in the number } \\
\text { of seizures occurred after } 6 \text { months of } \\
\text { treatment. }\end{array}$ & Tlusta et $\mathrm{al}^{35}$ \\
\hline India & $\begin{array}{l}\text { Phenobarbital } \\
\text { Carbamazepine } \\
\text { Phenytoin } \\
\text { Valproate } \\
\text { Clobazam } \\
\text { Clonazepam } \\
\text { Lamotrigine } \\
\text { Oxcarbazepine }\end{array}$ & $\begin{array}{l}\text { Generalized and } \\
\text { partial onset } \\
\text { elderly population }\end{array}$ & Retrospective & One year remission rate was $56 \%$ & Tran et a ${ }^{59}$ \\
\hline India & $\begin{array}{l}\text { Phenobarbital } \\
\text { or phenytoin }\end{array}$ & $\begin{array}{l}\text { Generalized and } \\
\text { partial onset }\end{array}$ & $\begin{array}{l}\text { Prospective } \\
\text { observational }\end{array}$ & $\begin{array}{l}\text { The proportion with remission at each of } \\
\text { four successive years of follow-up ranged } \\
\text { from } 58 \% \text { to } 66 \% \text { for patients who were } \\
\text { drug compliant and who had a lifetime } \\
\text { total of } 30 \text { or fewer generalized tonic- } \\
\text { clonic seizures. }\end{array}$ & Mani et $\mathrm{a}^{49}$ \\
\hline India & $\begin{array}{l}\text { Gabapentin } \\
\text { or Lamotrigine }\end{array}$ & $\begin{array}{l}\text { Partial onset } \\
\text { patients refractory } \\
\text { to carbamazepine }\end{array}$ & RCT & $\begin{array}{l}\text { The average frequency of partial seizures } \\
\text { decreased significantly in both groups. } \\
\text { The responder rate was } 78 \% \text { and } 92 \% \text { for } \\
\text { gabapentin and lamotrigine respectively. }\end{array}$ & Sethi et al ${ }^{10}$ \\
\hline Multiple & Lacosamide & Partial onset & RCT & $\begin{array}{l}\text { The median percent reduction in seizure } \\
\text { frequency was } 21 \% \text { for placebo, } 35 \% \\
\text { for lacosamide } 200 \mathrm{mg} / \text { day, and } 36 \% \text { for } \\
400 \mathrm{mg} / \text { day. }\end{array}$ & Halász et a $\left.\right|^{61}$ \\
\hline
\end{tabular}


Table 4 (Continued)

\begin{tabular}{|c|c|c|c|c|c|}
\hline Country & $\begin{array}{l}\text { Therapeutic } \\
\text { agent(s) }\end{array}$ & $\begin{array}{l}\text { Patient } \\
\text { population }\end{array}$ & Trial design & Key findings & Reference \\
\hline Multiple & $\begin{array}{l}\text { Eslicarbazepine } \\
\text { acetate }\end{array}$ & $\begin{array}{l}\text { Partial onset } \\
\text { patients refractory } \\
\text { to treatment with } \\
\text { one or two } \\
\text { concomitant AEDs }\end{array}$ & $\mathrm{RCT}$ & $\begin{array}{l}\text { Seizure frequency was significantly lower } \\
\text { in the treatment groups as compared } \\
\text { to placebo. }\end{array}$ & Elger et $\mathrm{a}^{62}$ \\
\hline Multiple & $\begin{array}{l}\text { Eslicarbazepine } \\
\text { acetate }\end{array}$ & Partial onset & $\begin{array}{l}\text { Prospective } \\
\text { observational }\end{array}$ & $\begin{array}{l}\text { Seizure frequency decreased by } 39 \% \\
\text { during the first } 4 \text { weeks and between } \\
48 \% \text { and } 56 \% \text { thereafter. }\end{array}$ & Halász et al ${ }^{19}$ \\
\hline Multiple & Valproate & $\begin{array}{l}\text { Generalized and } \\
\text { partial onset }\end{array}$ & $\begin{array}{l}\text { Prospective } \\
\text { observational }\end{array}$ & $\begin{array}{l}\text { At } 6 \text { months, } 77 \% \text { of subjects were } \\
\text { seizure free. }\end{array}$ & $\begin{array}{l}\text { Jedrzejczak } \\
\text { et } \mathrm{al}^{63}\end{array}$ \\
\hline Multiple & Valproate & Partial onset & $\begin{array}{l}\text { Prospective } \\
\text { observational }\end{array}$ & $\begin{array}{l}\text { At } 6 \text { months, } 87 \% \text { of patients became } \\
\text { seizure free. }\end{array}$ & Deleu et al ${ }^{64}$ \\
\hline Multiple & $\begin{array}{l}\text { Levetiracetam } \\
\text { as add-on agent }\end{array}$ & Partial onset & $\begin{array}{l}\text { Prospective } \\
\text { observational }\end{array}$ & $\begin{array}{l}44 \% \text { of patients had a } \geq 50 \% \text { reduction in } \\
\text { seizure frequency, with a median reduction } \\
\text { of } 46 \% .18 \% \text { became seizure free during } \\
\text { treatment. }\end{array}$ & Kwan et al ${ }^{65}$ \\
\hline Multiple & Oxcarbazepine & Partial onset & $\mathrm{RCT}$ & $\begin{array}{l}\text { The median reduction in seizure frequency } \\
\text { was } 26 \%, 40 \%, 50 \% \text {, or } 8 \% \text { for patients } \\
\text { receiving } 600,1200 \text {, or } 2400 \mathrm{mg} / \mathrm{d} \\
\text { treatment or placebo, respectively. } \\
\text { Of patients in the } 600,1200 \text {, or } 2400 \mathrm{mg} / \mathrm{d} \\
\text { treatment groups, } 27 \%, 42 \% \text {, and } 50 \% \\
\text { respectively, had more than } 50 \% \text { reduction } \\
\text { in seizure frequency compared } \\
\text { with I } 3 \% \text { for placebo. }\end{array}$ & Barcs et $a^{66}$ \\
\hline Poland & $\begin{array}{l}\text { Tiagabine as } \\
\text { add-on agent }\end{array}$ & $\begin{array}{l}\text { Generalized and } \\
\text { partial onset }\end{array}$ & $\begin{array}{l}\text { Prospective } \\
\text { observational }\end{array}$ & $\begin{array}{l}\text { The mean initial seizure rate per patient } \\
\text { decreased following treatment. } \\
\text { The percent of responders with } \geq 50 \% \\
\text { reduction of seizure rate reached } 52 \% \\
\text { after } 8 \text { weeks and } 77 \% \text { after } 16 \text { weeks. }\end{array}$ & $\begin{array}{l}\text { Chmielewska } \\
\text { and Stelmasiak }{ }^{67}\end{array}$ \\
\hline Poland & $\begin{array}{l}\text { Tiagabine as } \\
\text { add-on agent }\end{array}$ & $\begin{array}{l}\text { Generalized and } \\
\text { partial onset }\end{array}$ & $\begin{array}{l}\text { Prospective } \\
\text { observational }\end{array}$ & $\begin{array}{l}71 \% \text { patients had a } \geq 50 \% \text { decrease in } \\
\text { seizure frequency compared with baseline. } \\
\text { The beneficial effect of treatment on } \\
\text { seizure reduction was most marked in } \\
\text { patients with partial seizures. }\end{array}$ & Jedrzejczak ${ }^{68}$ \\
\hline Poland & $\begin{array}{l}\text { Topiramate as } \\
\text { add-on agent with } \\
\text { Carbamazepine }\end{array}$ & Partial onset & Retrospective & $\begin{array}{l}\text { Most AEs with adjunctive therapy } \\
\text { were transient. }\end{array}$ & $\begin{array}{l}\text { Majkowski } \\
\text { et al }{ }^{69}\end{array}$ \\
\hline Poland & $\begin{array}{l}\text { Lamotrigine vs } \\
\text { Valproate }\end{array}$ & Generalized & Retrospective & $\begin{array}{l}\text { Valproate showed comparable efficacy } \\
\text { in all syndromes where lamotrigine } \\
\text { showed better efficacy in childhood } \\
\text { epilepsy. }\end{array}$ & $\begin{array}{l}\text { Mazurkiewicz- } \\
\text { Beldzinska } \\
\text { et } \mathrm{al}^{70}\end{array}$ \\
\hline Russia & $\begin{array}{l}\text { Pregabalin as } \\
\text { add-on agent }\end{array}$ & Partial onset & $\begin{array}{l}\text { Prospective } \\
\text { observational }\end{array}$ & $\begin{array}{l}\text { The patients receiving treatment showed } \\
\text { a significant reduction at the end of the } \\
\text { first month in the number of seizures. }\end{array}$ & Bondarenko $\mathrm{III}^{71}$ \\
\hline Russia & $\begin{array}{l}\text { Oxcarbazepine } \\
\text { monotherapy } \\
\text { and as add-on agent }\end{array}$ & $\begin{array}{l}\text { Generalized and } \\
\text { partial onset }\end{array}$ & $\begin{array}{l}\text { Non } \\
\text { randomized } \\
\text { clinical trial }\end{array}$ & $\begin{array}{l}52 \% \text { of patients had } 50 \% \text { less seizures; } \\
35 \% \text { of patients had a reduced number of } \\
\text { seizures by } 75 \% \text {; I } 8 \% \text { of patients had full } \\
\text { control. In patients who never received } \\
\text { AED therapy, full treatment control was } \\
\text { achieved in } 74 \% \text { and among patients who } \\
\text { had received AED treatment full control } \\
\text { was reached in } 44 \% \text {. Monotherapy or } \\
\text { combined therapy also led to } \\
\text { decreased seizure duration. }\end{array}$ & Burd et $\mathrm{a}^{72}$ \\
\hline
\end{tabular}


Table 4 (Continued)

\begin{tabular}{|c|c|c|c|c|c|}
\hline Country & $\begin{array}{l}\text { Therapeutic } \\
\text { agent(s) }\end{array}$ & $\begin{array}{l}\text { Patient } \\
\text { population }\end{array}$ & Trial design & Key findings & Reference \\
\hline Russia & $\begin{array}{l}\text { Topiramate } \\
\text { anticonvulsant } \\
\text { monotherapy }\end{array}$ & $\begin{array}{l}\text { Generalized and } \\
\text { partial onset }\end{array}$ & $\begin{array}{l}\text { Prospective } \\
\text { observational }\end{array}$ & $\begin{array}{l}9.2 \% \text { of patients had an increase in and } \\
\text { duration of remission. Patients treated } \\
\text { with other drug therapy had much lower } \\
\text { rates of remission ( } 4.6 \% \text { for carbamazepine; } \\
3.0 \% \text { valproate; I.5\% phenobarbital). } \\
\text { Depression and anxiety developed twice } \\
\text { as frequently in women than men. }\end{array}$ & $\begin{array}{l}\text { Zheleznova } \\
\text { et } \mathrm{al}^{73}\end{array}$ \\
\hline South Korea & $\begin{array}{l}\text { Topiramate as } \\
\text { add-on therapy }\end{array}$ & $\begin{array}{l}\text { Partial onset } \\
\text { refractory }\end{array}$ & Retrospective & $\begin{array}{l}\text { The median seizure frequency reduction } \\
\text { rate was } 69 \% \text { in the treatment population. } \\
\text { Cumulative seizure-free rate was } 30 \% \text { and } \\
\text { the I-year seizure-free rate was } 13 \% \\
\text { at five-year follow-up. }\end{array}$ & Cho et $\mathrm{al}^{74}$ \\
\hline South Korea & Levetiracetam & $\begin{array}{l}\text { Partial onset } \\
\text { refractory }\end{array}$ & $\begin{array}{l}\text { Prospective } \\
\text { observational }\end{array}$ & $\begin{array}{l}\text { The median percent reduction in weekly } \\
\text { seizure frequency over the treatment } \\
\text { period was } 43.2 \% \text {. The } \geq 50 \% \text { and } \geq 75 \% \\
\text { responder rates were } 45.4 \% \text { and } 36.1 \% \text {, } \\
\text { respectively. }\end{array}$ & Heo et $\mathrm{al}^{75}$ \\
\hline South Korea & $\begin{array}{l}\text { AED drug } \\
\text { tapering }\end{array}$ & Generalized & Retrospective & $\begin{array}{l}75 \% \text { of patients achieved complete seizure } \\
\text { freedom for } \geq 1 \text { year. AED discontinuation } \\
\text { was attempted in } 91 \% \text { of patients with a } \\
\text { successful outcome. }\end{array}$ & Kim et $\mathrm{al}^{76}$ \\
\hline South Korea & $\begin{array}{l}\text { Pregabalin as } \\
\text { add-on therapy }\end{array}$ & $\begin{array}{l}\text { Partial onset } \\
\text { refractory }\end{array}$ & $\mathrm{RCT}$ & $\begin{array}{l}\text { There was a significant seizure reduction } \\
(52.7 \%) \text { with pregabalin compared to } \\
\text { placebo }(37.7 \%) \text {. }\end{array}$ & Lee et $\mathrm{al}^{77}$ \\
\hline Taiwan & $\begin{array}{l}\text { Levetiracetam } \\
\text { and topiramate } \\
\text { as add-on agents }\end{array}$ & Partial onset & $\begin{array}{l}\text { Prospective } \\
\text { observational }\end{array}$ & $\begin{array}{l}\text { Seizure frequency and epilepsy duration } \\
\text { were not significantly different between } \\
\text { the two groups compared to baseline. }\end{array}$ & Huang et $\mathrm{al}^{78}$ \\
\hline Taiwan & Levetiracetam & $\begin{array}{l}\text { Treatment- } \\
\text { resistant } \\
\text { partial onset } \\
\text { patients }\end{array}$ & $\mathrm{RCT}$ & $\begin{array}{l}\text { Levetiracetam reduced weekly partial- } \\
\text { seizure frequency by } 24 \% \text { relative to } \\
\text { placebo. Significantly more levetiracetam } \\
\text { than placebo patients experienced a } \\
\text { response of a } \geq 50 \% \text { decrease from baseline } \\
\text { in weekly frequency of partial seizures. }\end{array}$ & Tsai et $\mathrm{al}^{79}$ \\
\hline
\end{tabular}

Abbreviations: RCT, randomized controlled trial; AE, adverse event; AED, anti-epileptic drug.

of ' $50-100,000$ ' making comparisons to other countries impractical. ${ }^{12}$ Yet, the general prevalence of epilepsy in Colombia was determined to be $11.3 / 1000$ which was reported to be similar to prevalence rates found in nations with comparable developmental status. ${ }^{17}$

In developed countries, prevalence rates for epilepsy have been reported to range from $0.027-0.1$ per 1000 individuals. ${ }^{38,39}$ It is generally accepted that the prevalence rate in developing countries is approximately double that of developed countries, at approximately $0.15 / 1000 .{ }^{40}$ Variation in rates, between and within studies, may be attributable to differences in definitions of epilepsy and prevalence. For example, in the study by Banerjee and colleagues, ${ }^{38}$ the reported age-adjusted prevalence was based on medical records, whereas Onal and colleagues, used self-reported prevalence which was not confirmed by medical diagnoses. ${ }^{20}$ Yet, as prevalence is also a measure of the interaction of additional factors such as death, incidence, remission of illness, population migration, or access to appropriate medical care, it is likely that numerous factors account for the differences found between world populations, and not just differing methodologies. Population screening is needed to reveal the true epilepsy prevalence. Until broader, countrywide studies are performed, epidemiological rates will tend to be underestimated.

Incidence rates for North America and Europe have been reported to range from 16-51 per 100,000 people. ${ }^{38,39,41}$ These rates are at the lower end of global annual incidence estimates of 50-70 cases per $100,000 .{ }^{42}$ Only one study was identified in our review reporting an incidence of 174 per 100,000 persons in Qatar. ${ }^{12}$ However, this incidence study 
was regional, retrospective, hospital-based, and did not have a clear definition of epilepsy. Interpretation of the differences in incidence and prevalence rates will require additional awareness of the role of economic, cultural, and social factors effecting epilepsy and its care in these markets.

The primary focus of care for patients with epilepsy is the prevention of further seizures which may lead to additional morbidity or mortality. ${ }^{43}$ The goal of treatment is the maintenance of a normal lifestyle, ideally by complete seizure control without, or with, minimal side effects. If seizures are provoked by external factors, avoidance might be sufficient to prevent attacks. However, for the majority of patients, AED therapy is used. In addition to seizure control, patients with epilepsy may have psychosocial symptoms requiring treatment. But the quality of care and therapeutic outcome may differ across countries because of variations in medical systems. The Commission of European Affairs of the International League Against Epilepsy has defined standards for appropriate care, ${ }^{44}$ which have not yet been met by some European countries. ${ }^{45}$ As such, the situation in many developing countries is frequently less adequate. Few studies were identified that addressed ways by which care providers could more effectively identify patients with epilepsy or suggest an appropriate therapy, but in the studies reviewed for this report, the use of AEDs resulted in an increase of patients who had a decreased seizure burden.

In 2005, Garcia-Contreras et al reported the annual health care cost per treated patient in Mexico to be US\$2646. ${ }^{30}$ In the US, this number has been reported to be in the range of US\$2600-9400 per person. ${ }^{46,47}$ It should be noted, however, that these values from the year 2000 provide an outdated estimate of the direct costs of epilepsy, and it is reasonable to assume that in current monetary terms this burden is greater. Again, the differences between regions may be due to multiple factors including an underestimation of the affected population due to limited resources or, perhaps, the use of less expensive generic drugs over branded products. In 1999, phenytoin (dilantin) had a 42\% market share of all AED prescriptions in the US. ${ }^{48}$ The introduction of new AEDs over the past decade, including gabapentin, felbamate, lamotrigine, tiagabine, and topiramate, has increased the options available for adjunctive treatment when first-line therapy is ineffective. Many of these newer medications, however, often have increased tolerability and are beginning to replace their preceding agents as first-line therapy. ${ }^{48}$ In fact, in 2004, phenytoin's US market share had dropped to $33 \%{ }^{48}$ Yet, while the newer, branded medications are available in many emerging markets, resources are often limited and the inexpensive, effective generic AEDs are often used out of necessity. For example, Mani et al demonstrated successful treatment of epilepsy in a rural area of India using a combination of trained physicians and health workers, generic AEDs, drug compliance, health education, and follow-up. ${ }^{49}$ Further analyses considering cost-minimization, cost-effectiveness, and cost-benefit must be done in the future to further understand the cost of epilepsy therapy to resource-poor regions.

Epilepsy care in developing countries lags behind care in developed countries. Precise data on delivery of neurological services for epilepsy is vital to optimize medical services for patients with limited resources. This review additionally highlighted the need for the development of treatment strategies, counseling therapies, and social support services for people with epilepsy. ${ }^{34}$ Facilities for epilepsy surgery, therapeutic drug monitoring, and clinical psychologist or medical social worker services are also needed, as are educational interventions to improve the awareness of epilepsy misconceptions, and to end social discrimination against patients with epilepsy. ${ }^{36,37}$

Other limitations must be considered when evaluating the literature described in this review. One limitation of some of the literature included in this review is study design. Most of the evidence was derived from retrospective analyses of observational, uncontrolled studies. These study designs cannot lead to conclusions regarding causality, but rather provide correlative evidence. Sample sizes were generally large, however, the lack of statistical differences in certain factors found in some studies may have been due to an insufficient number of subjects in treatment groups. Additionally, selection and treatment bias towards individuals residing in a particular geographical region was inherent to some studies. Another limitation of this literature review was that results were limited to English. Some of the objectives (eg, treatment patterns, epidemiology) might have been explored in more detail in older literature and therefore would not have been captured in our search. Our search strategy also focused on peer-reviewed publications and did not capture information from abstracts, posters, or dissertations, which may have limited the amount of information assessed for this review. Lastly, all literature reviews are limited by publication bias with regard to the articles that are available.

\section{Conclusion}

This paper is an exhaustive examination of published literature describing many aspects of epilepsy in emerging 
markets. Overall, the reported incidence of epilepsy is low in the general population and, overall, treating patients with epilepsy is inexpensive and decreases the use of health care resources.

However, the identified clinical studies generally lacked standardized diagnosis criteria and used ineffectual methods with which to grade symptoms. Standards of care and baseline medications varied greatly between populations and adjunctive medications were often arbitrarily examined. Studies with longer follow-up periods and larger patient populations are needed to document the long-term effectiveness of several AEDs. Many of the observations discussed in this review need to be further confirmed in larger prospective trials, and, looking for specific characteristics of patients responding to certain drugs may lead to useful guidelines for drug choice in treating epilepsy. Knowledge gained in these areas will enable improvement to the care of people with epilepsy both in emerging markets and elsewhere.

\section{Disclosure}

The authors declare no conflicts of interest in this work.

\section{References}

1. Epilepsy Fact Sheet No 999, January 2009. World Health Organization. 2009. Available at: http://www.who.int/mediacentre/factsheets/fs999/ en/index.html. Accessed on September 27, 2011.

2. Proposal for revised classification of epilepsies and epileptic syndromes. Commission on Classification and Terminology of the International League Against Epilepsy. Epilepsia. 1989;30(4):389-399.

3. Schachter SC. Seizure disorders. Med Clin North Am. 2009;93(2): 343-351.

4. French JA, Kanner AM, Bautista J, et al. Efficacy and tolerability of the new anti-epileptic drugs II: Treatment of refractory epilepsy. Neurology. 2004;62(8):1261-1273.

5. Heakal R. What Is An Emerging Market Economy? 2009. Available at: http://www.investopedia.com/articles/03/073003.asp\#axzz1Z4eUuEFk. Accessed on April 20, 2011.

6. Newton CR. Status epilepticus in resource-poor countries. Epilepsia. 2009;50(12):54-55.

7. International League Against Epilepsy [homepage]. Available at: www. ilae-epilepsy.org. Accessed on April 20, 2011.

8. Somoza MJ, Forlenza RH, Brussino M, Licciardi L. Epidemiological survey of epilepsy in the primary school population in Buenos Aires. Neuroepidemiology. 2005;25(2):62-68.

9. Melcon MO, Kochen S, Vergara RH. Prevalence and clinical features of epilepsy in Argentina. A community-based study. Neuroepidemiology. 2007;28(1):8-15.

10. Somoza MJ, Forlenza RH, Brussino M, Centurión E. Epidemiological survey of epilepsy in the special school population in the city of Buenos Aires. A comparison with mainstream schools. Neuroepidemiology. 2009;32(2):129-135.

11. Al Rajeh S, Awada A, Bademosi O, Ogunniyi A. The prevalence of epilepsy and other seizure disorders in an Arab population: a community-based study. Seizure. 2001;10(6):410-414.

12. Benamer HT, Grosset DG. A systematic review of the epidemiology of epilepsy in Arab countries. Epilepsia. 2009;50(10):2301-2304.
13. Kwong KL, Chak WK, Wong SN, So KT. Epidemiology of childhood epilepsy in a cohort of 309 Chinese children. Pediatr Neurol. 2001; 24(4):276-282.

14. Fong GC, Mak W, Cheng TS, Chan KH, Fong JK, Ho SL. A prevalence study of epilepsy in Hong Kong. Hong Kong Med J. 2003;9(4): 252-257.

15. Hui AC, Lam JM, Wong KS, Kay R, Poon WS. Vagus nerve stimulation for refractory epilepsy: long term efficacy and side-effects. Chin Med $J$ (Engl). 2004;117(1):58-61.

16. Chen CC, Chen TF, Hwang YC, et al. Population-based survey on prevalence of adult patients with epilepsy in Taiwan (Keelung community-based integrated screening no.12). Epilepsy Res. 2006; 72(1):67-74.

17. Velez A, Eslava-Cobos J. Epilepsy in Colombia: epidemiologic profile and classification of epileptic seizures and syndromes. Epilepsia. 2006;47(1):193-201.

18. Shah PA, Shapoo SF, Koul RK, Khan MA. Prevalence of epilepsy in school-going children (6-18 years) in Kashmir Valley of North-west India. J Indian Med Assoc. 2009;107(4):216-218.

19. Halász P, Cramer JA, Hodoba D, et al; BIA-2093-301 Study Group. Long-term efficacy and safety of eslicarbazepine acetate: results of a 1-year open-label extension study in partial-onset seizures in adults with epilepsy. Epilepsia. 2010;51(10):1963-1969.

20. Onal AE, Tumerdem Y, Ozturk MK, et al. Epilepsy prevalence in a rural area in Istanbul. Seizure. 2002;11(6):397-401.

21. Serdaroğlu A, Ozkan S, Aydin K, Gücüyener K, Tezcan S, Aycan S. Prevalence of epilepsy in Turkish children between the ages of 0 and 16 years. J Child Neurol. 2004;19(4):271-274.

22. Calisir N, Bora I, Irgil E, Boz M. Prevalence of epilepsy in Bursa city center, an urban area of Turkey. Epilepsia. 2006;47(10): 1691-1699.

23. Velioglu SK, Bakirdemir M, Can G, Topbas M. Prevalence of epilepsy in northeast Turkey. Epileptic Disord. 2010;12(1):22-37.

24. Hong Z, Qu B, Wu XT, Yang TH, Zhang Q, Zhou D. Economic burden of epilepsy in a developing country: a retrospective cost analysis in China. Epilepsia. 2009;50(10):2192-2198.

25. Rane CT, Dalvi SS, Gogtay NJ, Shah PU, Kshirsagar NA. A pharmacoeconomic analysis of the impact of therapeutic drug monitoring in adult patients with generalized tonic-clonic epilepsy. Br J Clin Pharmacol. 2001;52(2):193-195.

26. Suh GH, Lee SK. Economic Evaluation of Add-on Levetiracetam for the Treatment of Refractory Partial Epilepsy in Korea. Psychiatry Investig. 2009;6(3):185-193.

27. Balabanov PP, Zahariev ZI, Mateva NG. Evaluation of the factors affecting the quality of life and total costs in epilepsy patients on monotherapy with carbamazepine and valproate. Folia Med (Plovdiv). 2008;50(2):18-23.

28. Ding D, Hong Z, Chen GS, et al. Primary care treatment of epilepsy with phenobarbital in rural China: cost-outcome analysis from the WHO/ ILAE/IBE global campaign against epilepsy demonstration project. Epilepsia. 2008;49(3):535-539.

29. Thomas SV, Koshy S, Nair CR, Sarma SP. Frequent seizures and polytherapy can impair quality of life in persons with epilepsy. Neurol India. 2005;53(1):46-50.

30. Garcia-Contreras F, Constantino-Casas P, Castro-Rios A, et al. Direct medical costs for partial refractory epilepsy in Mexico. Arch Med Res. 2006;37(3):376-383.

31. Cowling BJ, Shaw JE, Hutton JL, Marson AG. New statistical method for analyzing time to first seizure: example using data comparing carbamazepine and valproate monotherapy. Epilepsia. 2007;48(6): 1173-1178.

32. Kochen S, Giagante B, Oddo S. Spike-and-wave complexes and seizure exacerbation caused by carbamazepine. Eur J Neurol. 2002;9(1):41-47.

33. Anand K, Jain S, Paul E, Srivastava A, Sahariah SA, Kapoor SK. Development of a validated clinical case definition of generalized tonic-clonic seizures for use by community-based health care providers. Epilepsia. 2005;46(5):743-750. 
34. Otoom S, Al-Jishi A, Montgomery A, Ghwanmeh M, Atoum A. Death anxiety in patients with epilepsy. Seizure. 2007;16(2):142-146.

35. Tlusta E, Zarubova J, Simko J, Hojdikova H, Salek S, Vlcek J. Clinical and demographic characteristics predicting QOL in patients with epilepsy in the Czech Republic: how this can influence practice. Seizure. 2009;18(2):85-89.

36. Thomas SV, Sarma PS, Alexander M, et al. Epilepsy care in six Indian cities: a multicenter study on management and service. J Neurol Sci. 2001;188(1-2):73-77.

37. Awad A, Sarkhoo F. Public knowledge and attitudes toward epilepsy in Kuwait. Epilepsia. 2008;49(4):564-572.

38. Banerjee PN, Filippi D, Allen Hauser W. The descriptive epidemiology of epilepsy-a review. Epilepsy Res. 2009;85(1):31-45.

39. Theodore WH, Spencer SS, Wiebe S, et al. Epilepsy in North America: a report prepared under the auspices of the global campaign against epilepsy, the International Bureau for Epilepsy, the International League Against Epilepsy, and the World Health Organization. Epilepsia. 2006;47(10): 1700-1722.

40. Strzelczyk A, Reese JP, Dodel R, Hamer HM. Cost of epilepsy: a systematic review. Pharmacoeconomics. 2008;26(6):463-476.

41. Cross SA, Curran MP. Lacosamide: in partial-onset seizures. Drugs. 2009;69(4):449-459.

42. Stephen LJ, Brodie MJ. Pharmacotherapy of epilepsy: newly approved and developmental agents. CNS Drugs. 2011;25(2):89-107.

43. Kwan P, Brodie MJ. Clinical trials of antiepileptic medications in newly diagnosed patients with epilepsy. Neurology. 2003;60(11 Suppl 4): S2-S12.

44. Brodie MJ, Shorvon SD, Canger R, et al. Commission on European Affairs: appropriate standards of epilepsy care across Europe. ILEA. Epilepsia. 1997;38(11):1245-1250.

45. Malmgren K, Flink R, Guekht AB, et al. ILAE Commission of European Affairs Subcommission on European Guidelines 1998-2001: The provision of epilepsy care across Europe. Epilepsia. 2003;44(5): 727-731.

46. Begley CE, Famulari M, Annegers JF, et al. The cost of epilepsy in the United States: an estimate from population-based clinical and survey data. Epilepsia. 2000;41(3):342-351.

47. Wiebe S. Burden of intractable epilepsy. Adv Neurol. 2006;97: $1-4$.

48. Uthman BM, Beydoun A. Less commonly used antiepileptic drugs. The treatment of epilepsy: principles and practice. 4 ed. Baltimore, MD: Lippincott, Williams and Wilkins; 2006:947.

49. Mani KS, Rangan G, Srinivas HV, Srindharan VS, Subbakrishna DK. Epilepsy control with phenobarbital or phenytoin in rural south India: the Yelandur study. Lancet. 2001;357(9265):1316-1320.

50. Montenegro MA, Cendes F, Noronha AL, et al. Efficacy of clobazam as add-on therapy in patients with refractory partial epilepsy. Epilepsia. 2001;42(4):539-542.

51. Montenegro MA, Ferreira CM, Cendes F, Li LM, Guerreiro CA. Clobazam as add-on therapy for temporal lobe epilepsy and hippocampal sclerosis. Can J Neurol Sci. 2005;32(1):93-96.

52. Liu L, Zhang Q, Yao Z, et al. The operational model of a network for managing patients with convulsive epilepsy in rural West China. Epilepsy Behav. 2010;17(1):75-81.

53. Lu Y, Wang X, Li Q, Li J, Yan Y. Tolerability and safety of topiramate in Chinese patients with epilepsy: an open-label, long-term, prospective study. Clin Drug Investig. 2007;27(10):683-690.

54. Lu Y, Xiao Z, Yu W, et al. Efficacy and safety of adjunctive zonisamide in adult patients with refractory partial-onset epilepsy: a randomized, double-blind, placebo-controlled trial. Clin Drug Investig. 2011; 31(4):221-229.

55. Lu Y, Yu W, Wang X. Efficacy of topiramate in adult patients with symptomatic epilepsy: an open-label, long-term, retrospective observation. CNS Drugs. 2009;23(4):351-359.

56. Sun MZ, Deckers CL, Liu YX, Wang W. Comparison of add-on valproate and primidone in carbamazepine-unresponsive patients with partial epilepsy. Seizure. 2009;18(2):90-93.
57. Wu XY, Hong Z, Wu X, et al. Multicenter double-blind, randomized, placebo-controlled trial of levetiracetam as add-on therapy in Chinese patients with refractory partial-onset seizures. Epilepsia. 2009;50(3): 398-405.

58. Xiao Z, Li JM, Wang XF, et al. Efficacy and safety of levetiracetam $(3,000 \mathrm{mg} /$ Day $)$ as an adjunctive therapy in Chinese patients with refractory partial seizures. Eur Neurol. 2009;61(4):233-239.

59. Tran KT, Hranicky D, Lark T, Jacob NJ. Gabapentin withdrawal syndrome in the presence of a taper. Bipolar Disord. 2005;7(3): 302-304.

60. Sethi A, Chandra D, Puri V, Mallika V. Gabapentin and lamotrigine in Indian patients of partial epilepsy refractory to carbamazepine. Neurol India. 2002;50(3):359-363.

61. Halász P, Kälviäinen R, Mazurkiewicz-Bełdzińska M, et al; SP755 Study Group. Adjunctive lacosamide for partial-onset seizures: Efficacy and safety results from a randomized controlled trial. Epilepsia. 2009;50(3):443-453.

62. Elger C, Halász P, Maia J, Almeida L, Soares-da-Silva P; BIA-2093-301 Investigators Study Group. Efficacy and safety of eslicarbazepine acetate as adjunctive treatment in adults with refractory partial-onset seizures: a randomized, double-blind, placebo-controlled, parallel-group phase III study. Epilepsia. 2009;50(3):454-463.

63. Jedrzejczak J, Kunciková M, Magureanu S; VIPe Study Group. An observational study of first-line valproate monotherapy in focal epilepsy. Eur J Neurol. 2008;15(1):66-72.

64. Deleu D, Al-Hail H, Mesraoua B, Mahmoud HA; Gulf Vipe Study Group. Short-term efficacy and safety of valproate sustainedrelease formulation in newly diagnosed partial epilepsy VIPe-study. A multicenter observational open-label study. Saudi Med J. 2007;28(9): 1402-1407.

65. Kwan P, Lim SH, Chinvarun Y, Cabral-Lim L, Aziz ZA, Lo YK, et al. Efficacy and safety of levetiracetam as adjunctive therapy in adult patients with uncontrolled partial epilepsy: the Asia SKATE II Study. Epilepsy Behav. 2010;18(1-2):100-105.

66. Barcs G, Walker EB, Elger CE, et al. Oxcarbazepine placebo-controlled, dose-ranging trial in refractory partial epilepsy. Epilepsia. 2000;41(12): 1597-1607.

67. Chmielewska B, Stelmasiak Z. GABI-balance - a non-interventional observational study on the effectiveness of tiagabine in add-on therapy in partial epilepsy. Neurol Neurochir Pol. 2008;42(4):303-311.

68. Jedrzejczak J. Tiagabine as add-on therapy may be more effective with valproic acid - open label, multicentre study of patients with focal epilepsy. Eur J Neurol. 2005;12(3):176-180.

69. Majkowski J, Neto W, Wapenaar R, Van Oene J. Time course of adverse events in patients with localization-related epilepsy receiving topiramate added to carbamazepine. Epilepsia. 2005;46(5):648-653.

70. Mazurkiewicz-Beldzinska M, Szmuda M, Matheisel A. Long-term efficacy of valproate versus lamotrigine in treatment of idiopathic generalized epilepsies in children and adolescents. Seizure. 2010;19(3): 195-197.

71. Bondarenko II. Experience in the use of the anticonvulsant pregabalin as an add-on therapy in patients with partial epilepsy with polymorphic seizures. Neurosci Behav Physiol. 2010;40(2):163-164.

72. Burd SG, Glukhova LI, Badalian OL. Efficacy and safety of the monoand combined therapy with oxcarbazepine in adult patients. Zh Nevrol Psikhiatr Im S S Korsakova. 2010;110(6):66-69. Russian.

73. Zheleznova EV, Kalinin VV, Zemlyanaya AA, Sokolova LV, Medvedev IL. Monotherapy of epilepsy in women: psychiatric and neuroendocrine aspects. Neurosci Behav Physiol. 2010;40(2):157-162.

74. Cho YJ, Heo K, Kim WJ, et al. Long-term efficacy and tolerability of topiramate as add-on therapy in refractory partial epilepsy: an observational study. Epilepsia. 2009;50(8):1910-1919.

75. Heo K, Lee BI, Yi SD, et al. Efficacy and safety of levetiracetam as adjunctive treatment of refractory partial seizures in a multicentre open-label single-arm trial in Korean patients. Seizure. 2007;16(5): 402-409. 
76. Kim YD, Heo K, Park SC, et al. Antiepileptic drug withdrawal after successful surgery for intractable temporal lobe epilepsy. Epilepsia. 2005;46(2):251-257.

77. Lee BI, Yi S, Hong SB, et al. Pregabalin add-on therapy using a flexible, optimized dose schedule in refractory partial epilepsies: a double-blind, randomized, placebo-controlled, multicenter trial. Epilepsia. 2009; 50(3):464-474.
78. Huang CW, Pai MC, Tsai JJ. Comparative cognitive effects of levetiracetam and topiramate in intractable epilepsy. Psychiatry Clin Neurosci. 2008;62(5):548-553.

79. Tsai JJ, Yen DJ, Hsih MS, et al. Efficacy and safety of levetiracetam (up to $2000 \mathrm{mg}$ /day) in Taiwanese patients with refractory partial seizures: a multicenter, randomized, double-blind, placebo-controlled study. Epilepsia. 2006;47(1):72-81.

\section{Publish your work in this journal}

Neuropsychiatric Disease and Treatment is an international, peerreviewed journal of clinical therapeutics and pharmacology focusing on concise rapid reporting of clinical or pre-clinical studies on a range of neuropsychiatric and neurological disorders. This journal is indexed on PubMed Central, the 'PsycINFO' database and CAS, and is the official

Submit your manuscript here: http://www.dovepress.com/neuropsychiatric-disease-and-treatment-journal journal of The International Neuropsychiatric Association (INA). The manuscript management system is completely online and includes a very quick and fair peer-review system, which is all easy to use. Visit http://www.dovepress.com/testimonials.php to read real quotes from published authors. 